\title{
Microwave drying of wet processed wood fibre insulating boards
}

\author{
Michael Bartholme · Georg Avramidis · Wolfgang Viöl · Alireza Kharazipour
}

Received: 11 September 2008 / Published online: 6 February 2009

(C) Springer-Verlag 2009

Subject A continuous microwave dryer was used for drying wet processed wood fibre based insulating boards. Drying characteristics and energy consumption were compared with convective drying methods. Microwave drying turned out to be faster and facilitates even economical drying of thick boards.

\section{Introduction}

The reduction of drying times and energy consumption are incessant goals in industrial drying processes. In recent years the microwave technique has been established in different sectors of industry as an efficient drying method (Metaxas and Meredith 1983, Meredith 1998). Several investigations on microwave drying of wood and wood based materials have recently been carried out (Hansson and Antti 2003, Seyfarth et al. 2003, Hunt et al. 2005). In microwave heating, the electromagnetic energy is directly transferred into the material, absorbed by molecules and converted into heat energy; as a consequence the temperature rises much faster compared to conventional drying (Zielonka and Gierlik 1999). These properties have also

\footnotetext{
M. Bartholme · G. Avramidis · W. Viöl (『)

Department of Sciences and Technology,

University of Applied Sciences and Arts,

Von-Ossietzky-Strasse 99,

37085 Göttingen, Germany

e-mail: vioel@hawk-hhg.de

G. Avramidis · A. Kharazipour

Büsgeninstitut, University of Göttingen,

Büsgenweg 2,

37077 Göttingen, Germany
}

been investigated for the drying of wet-formed biological materials, e.g. drying of bran-based packing material (Ansorge 1997). For the production of wood fibre-based insulating boards without binders only the wet process is used. The bonding forces of wood and the interlocking of fibres result in effective stabilisation of insulating boards so that it is possible to leave out adhesive agents (Lampert 1967). The drying of these wood fibre mats is conducted in gas heated drying kilns (convective drying). Convective drying of insulating boards, $20 \mathrm{~mm}$ thick, requires approximately 2 hours at between 160 and $220^{\circ} \mathrm{C}$. Convective drying of insulating boards over $20 \mathrm{~mm}$ thickness requires additional time and is therefore not cost-efficient and usually not used industrially. Accordingly, boards over $20 \mathrm{~mm}$ thickness are produced by gluing together several layers of thin boards. In this study microwave drying of wood fibre-based insulating boards is investigated with regard to drying time, core temperature and energy consumption. To compare microwave drying with industrial convective techniques, drying has also been conducted in a laboratory drying cabinet at a temperature of $170{ }^{\circ} \mathrm{C}$. Tests with insulating boards of $20 \mathrm{~mm}$ thickness revealed that drying times in the laboratory drying cabinet are comparable with drying times of industrially scaled drying kilns. Furthermore the total energy consumption per kilogram of evaporated water for microwave drying was assessed and compared with literature values for convective dryers.

\section{Experimental}

Insulating boards of beech fibres with dimensions $300 \times$ $500 \times 20 \mathrm{~mm}^{3}$ were produced. For this purpose a suspen- 
sion with a solid content of $2.5 \%$ was made of $500 \mathrm{~g}$ wood fibres and tap water and stirred for $1 \mathrm{~h}$. Subsequently the suspension was put into a casting mould and the suspension was drained. The fibre mat thus obtained was put into a cold press for 2 min until the water content reached $120 \%$, which corresponds to $1100 \mathrm{~g}$ of the fibre mat. These boards were dried in a microwave dryer with an oscillating conveyor belt (MWDA $6.6 \mathrm{~kW}$, Fricke und Mallah Microwave Technology GmbH, Peine, Germany, airflow $=200 \mathrm{~m}^{3} / \mathrm{h}$ ) and in a conventional drying cabinet (UFE 800, Memmert GmbH \& Co. KG, Schwabach, Germany, air flow = $19 \mathrm{~m}^{3} / \mathrm{h}$ ) at $170^{\circ} \mathrm{C}$ to give a water content of approximately $5 \%$. The water content was measured every minute during microwave drying and every $10 \mathrm{~min}$ during convective drying by weighing the samples. The difference between the measured weight and the weight of solid gave the water content; the difference between the measured weight and start weight of the fibre mat yielded the mass $m_{\mathrm{W}}$ of evaporated water. The core temperatures of the insulating boards during the drying process were measured with a fibre-optical thermometer (FTI 10, FISO Technologies, Canada) and its corresponding software (FISOCommander, FISO Technologies, Canada). The energy consumption per kilogram of evaporated water was calculated from the total electric input power $P_{\mathrm{t}}$ of the continuous microwave dryer (magnetrons, conveyer belt, ventilators), measured using an electric power meter, the mass of the evaporated water $m_{\mathrm{W}}$ and the drying time $t_{\mathrm{d}}$ :

$E / m=P_{\mathrm{t}} / m_{\mathrm{W}} t_{\mathrm{d}}$.

\section{Results and discussion}

Figures 1 and 2 show the drying characteristics of insulating boards $(t=20 \mathrm{~mm})$ dried in the drying cabinet and in the continuous microwave dryer. For each test parameter 3-5 samples were assayed. The drying curve (water content) for convective drying at $170^{\circ} \mathrm{C}$ (Fig. 1) follows an exponential decay and the drying rate decreases with elapsed time. The drying process for $20 \mathrm{~mm}$ thick insulating boards was completed in $110 \mathrm{~min}$. The core temperature for convective drying reaches the first maximum of $87^{\circ} \mathrm{C}$ after approximately $20 \mathrm{~min}$. As the drying process continues the temperature drops to $77^{\circ} \mathrm{C}$, due to the increasing insulating effect of the dried wood fibres and the cooling effect of evaporation. After $80 \mathrm{~min}$ and at a water content of $20 \%$, the core temperature rises to approximately $140^{\circ} \mathrm{C}$ at which temperature the drying process is complete. Figure 2 shows the drying curve (water content) of microwave dried insulating boards. The curve remains almost linear and the drying process is significantly accelerated compared to the convectively dried insulating boards. For microwave drying the drying process of $20 \mathrm{~mm}$ thick insulating boards is complete after $9 \mathrm{~min}$. The core temperature increases to approx. $100^{\circ} \mathrm{C}$ within $2 \mathrm{~min}$ and remains unchanged until the total water content falls below $30 \%$. After 7 min drying and at a water content of less than $30 \%$ the microwaves heat the wooden material so that a significant temperature rise occurs due to the lack of evaporative cooling at the dry core. The total energy consumption for the microwave drying of $20 \mathrm{~mm}$ thick insulating boards was determined from Eq. 1
Fig. 1 Water content and core temperature versus drying time for convective drying

Abb. 1 Feuchtigkeitsverlauf und Kerntemperatur bei konvektiver Trocknung

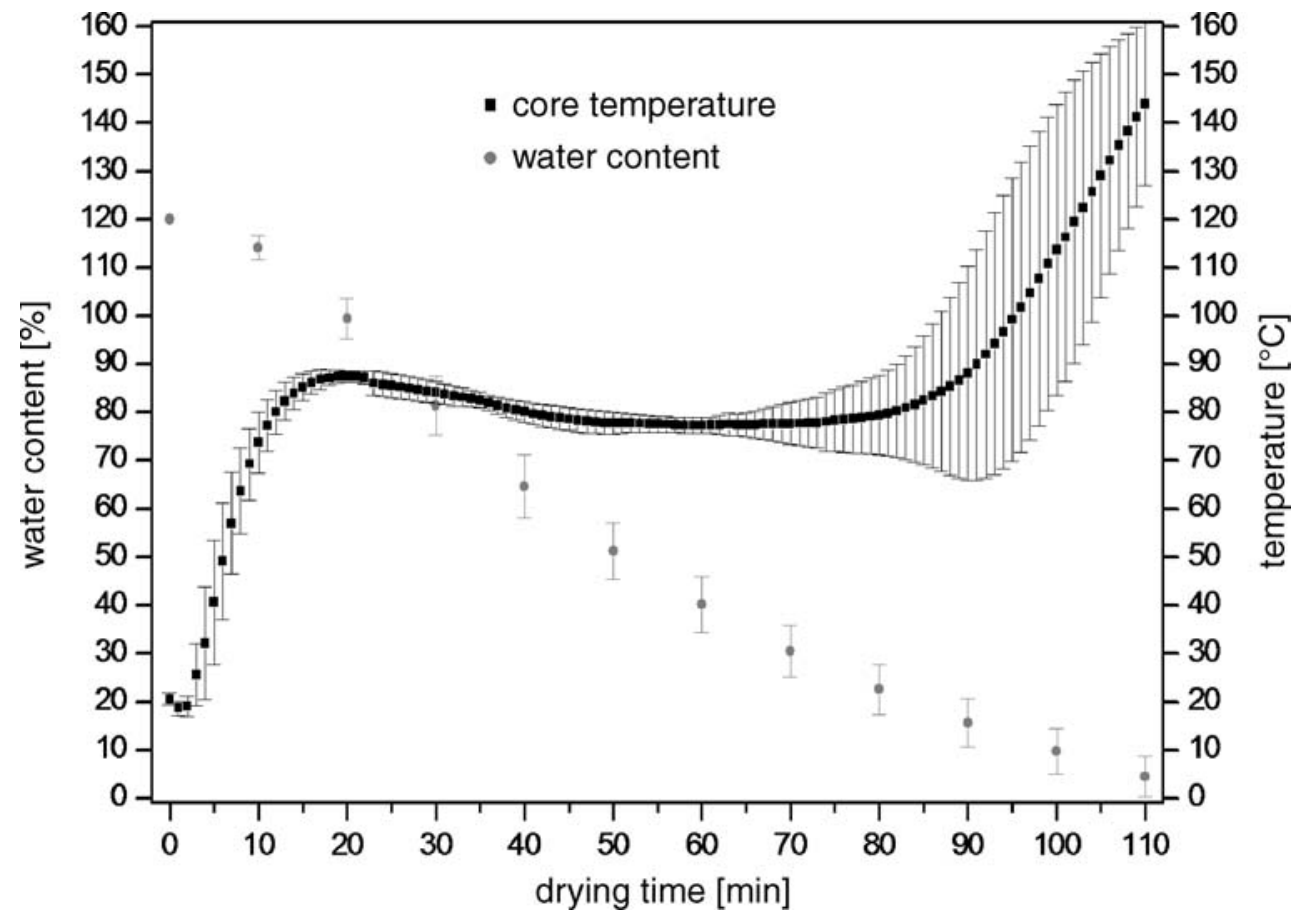


Fig. 2 Water content and core temperature versus drying time for microwave drying

Abb. 2 Feuchtigkeitsverlauf und Kerntemperatur bei Mikrowellentrocknung

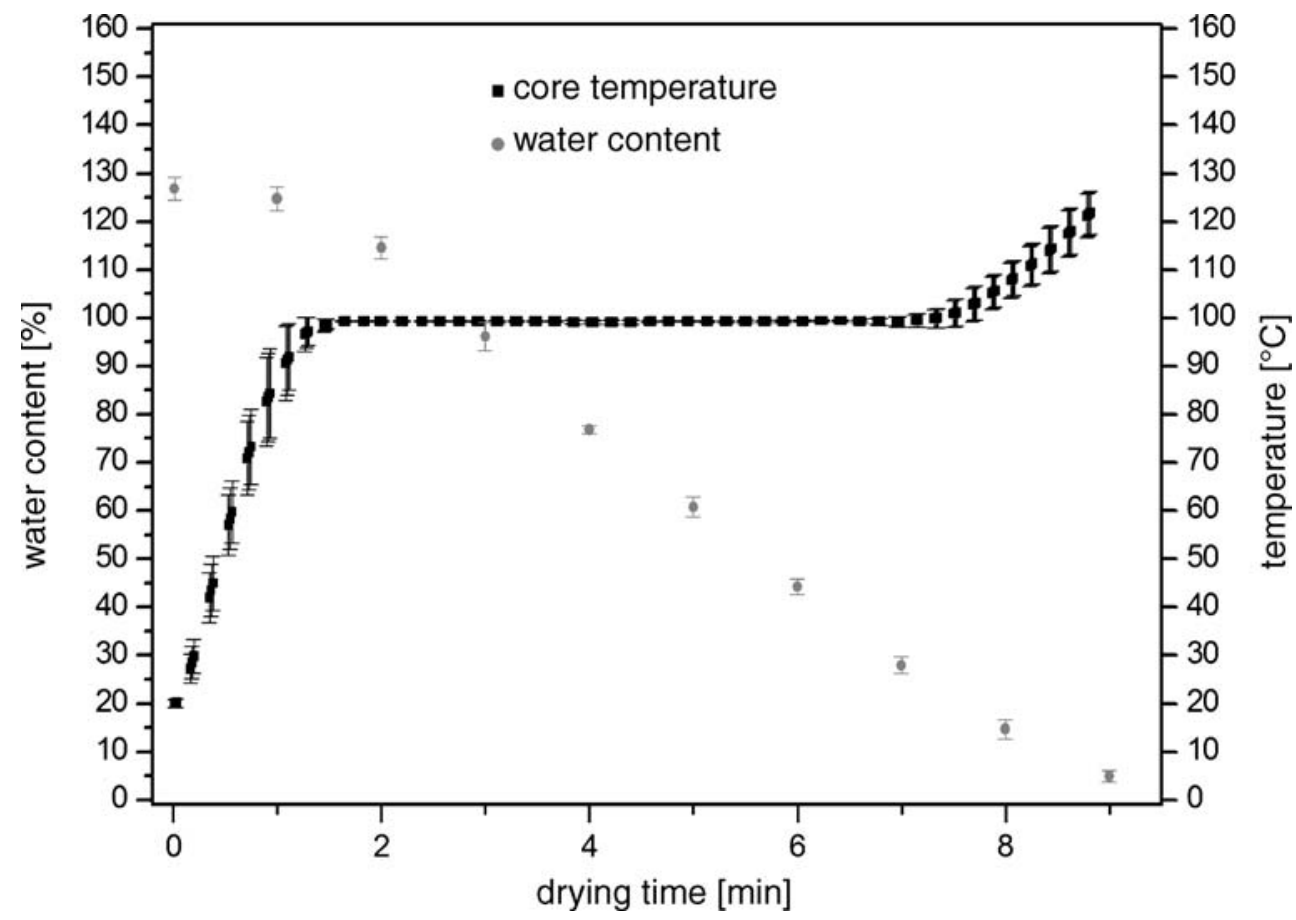

using values for the total electric input power $P_{\mathrm{t}} 5.25 \mathrm{~kW}$, a drying time $t_{\mathrm{d}}$ of approximately $540 \mathrm{~s}$ and a mass of evaporated water $m_{\mathrm{W}} 600 \mathrm{~g}$. For these values the energy consumption per kilogram of evaporated water was determined to be approximately $4700 \mathrm{~kJ} / \mathrm{kg}$, which is in the range of energy consumption reported in the literature for typical convective band dryers (Mujumdar 1995).

To prove whether microwave drying of boards of more than $20 \mathrm{~mm}$ thickness is achievable within an economic time, additional drying tests with boards of 30,40 and $50 \mathrm{~mm}$ thickness were conducted without a detailed investigation of moisture content progression and core temperature. Table 1 summarizes the results of these experiments. In all cases it is possible to dry the insulating boards in a fraction of the time required for convectively dried boards, so by microwave technology it is possible to omit gluing processes for the production of insulating boards thicker than $20 \mathrm{~mm}$. For $30 \mathrm{~mm}$ boards the drying times can be reduced by a factor 15 , for $40 \mathrm{~mm}$ boards by a factor 17 and for $50 \mathrm{~mm}$ boards by a factor 18 . This means that with increasing board thickness the drying process for microwave drying

Table 1 Drying times for 20, 30, 40 and $50 \mathrm{~mm}$ thick boards Tabelle 1 Trocknungszeiten für 20, 30, 40 und $50 \mathrm{~mm}$ Plattendicke

\begin{tabular}{lll}
\hline Board thickness & $\begin{array}{l}\text { Drying time } \\
\text { microwave dryer }\end{array}$ & $\begin{array}{l}\text { Drying time } \\
\text { drying cabinet }\end{array}$ \\
\hline $20 \mathrm{~mm}$ & $9 \mathrm{~min}$ & $110 \mathrm{~min}$ \\
$30 \mathrm{~mm}$ & $11 \mathrm{~min}$ & $170 \mathrm{~min}$ \\
$40 \mathrm{~mm}$ & $14 \mathrm{~min}$ & $240 \mathrm{~min}$ \\
$50 \mathrm{~mm}$ & $18 \mathrm{~min}$ & $330 \mathrm{~min}$ \\
\hline
\end{tabular}

becomes significant more efficient compared to convective dryings.

Microwave dried boards were equal to convectively dried boards regarding appearance and stability. Tests of the tensile strength according to DIN EN 1607 revealed no differences in internal bond strength between microwave dried and convectively dried insulating boards

\section{Conclusion}

It has been shown that microwave drying of wet processed fibre mats of $20 \mathrm{~mm}$ thickness can reduce the drying process by a factor 12 , whereas the energy consumption per kilogram of evaporated water is comparable to convective dryers. Furthermore it was shown that insulating boards of thickness greater than $20 \mathrm{~mm}$ can be produced in an economic time by microwave technology. The stability properties of the boards were not negatively affected by microwave drying compared to convective drying. For the microwave dried boards, an abrupt temperature rise at a water content of approximately $20-30 \%$ demands process control to prevent material ignition.

Acknowledgement Grateful thanks to the Federal Ministry of Education and Research (BMBF, Projektträger Jülich PTJ) for financial support of network project ,Verwertungsorientierte Untersuchungen an Buche und Küstentanne aus nachhaltig bewirtschafteten Mischbeständen zur Herstellung innovativer, zukunftsfähiger Holzprodukte und Holzwerkstoffe“. The authors would like to thank the Fricke und Mallah GmbH for their great support. 


\section{References}

Ansorge T (1997) Beitrag zur Entwicklung von Herstellverfahren für ein stoßabsorbierendes Verpackungsmaterial auf Basis von Getreidekleie. Chemnitz

DIN EN 1607 (1997) Wärmedämmstoffe für das Bauwesen - Bestimmung der Zugfestigkeit senkrecht zur Plattenebene

Hansson L, Antti A-L (2003) The effect of microwave drying on norway spruce woods strength: a comparison with conventional drying. J Mater Proc Technol 141(1):41-50

Hunt J-R, Gu H, Walsh P, Winandy J-E (2005) Development of new microwave-drying and straightening technology for low value curved timber. F. P. Laboratory, US Department of Agriculture

Lampert H (1967) Faserplatten. VEB Fachbuchverlag, Leipzig
Meredith R-J (1998) Engineers' Handbook of Industrial Microwave Heating. IEE Power Series 25. Institution of Electrical Engineers, London

Metaxas A-C, Meredith R-J (1983) Industrial Microwave Heating, IEE Power Engineering Series. Institution of Engineering and Technology, London

Mujumdar A-S (1995) Handbook of Industrial Drying, 2nd Ed. New York

Seyfarth R, Leiker M, Mollekopf N (2003) Continuous drying of lumber in a microwave vacuum kiln. 8th International IUFRO Wood Drying Conference

Zielonka P, Gierlik E (1999) Temperature distribution during conventional and microwave wood heating. Holz Roh- Werkst 57(4):247-249 